\title{
IDENTIFIKASI EKSPRESI WAJAH UNTUK PEMBAYARAN
}

\section{FACIAL EXPRESSION RECOGNITION FOR PAYMENT}

\author{
Y Sutisnawati $^{1}$, M Muriani ${ }^{2}$, M Mirawati $^{3}$, N A Putri ${ }^{4}, \mathrm{C}$ N Albar ${ }^{5}$ \\ ${ }^{1}$ Program Studi Keuangan Perbankan, ${ }^{2}$ Program Studi Akuntansi \\ $3,4,5$ Program Studi Sastra Inggris \\ Universitas Komputer Indonesia \\ Email: yayah@unikom.ac.id
}

\begin{abstract}
Abstrak
Penelitian ini bertujuan untuk mengetahui akurasi dan efektivitas identifikasi pada sistem identifikasi ekspresi wajah jika digunakan sebagai sistem pembayaran transaksi jual beli suatu perusahaan. Metode penelitian ini adalah deskriptif, kualitatif, dan didukung oleh studi literatur. Hasil penelitian menunjukkan bahwa sistem identifikasi ekspresi wajah efektif jika diterapkan pada sistem pembayaran. Hal ini terlihat dari tingkat akurasi identifikasi dan efektivitas identifikasi ekspresi wajah yang lebih tinggi dari tingkat kegagalan, serta kemampuan mendeteksi wajah yang cepat. Selanjutnya menggabungkan teknologi deteksi keaktifan ke dalam identifikasi ekspresi wajah akan mencegah serangan spoof yang dilakukan oleh gambar non-nyata seperti foto potret. Oleh karena itu, dapat disimpulkan bahwa sistem identifikasi ekspresi wajah dapat menjadi salah satu sistem yang paling banyak diterapkan di masa depan. Hal ini dikarenakan kemudahan bertransaksi yang akan memberikan kemudahan bagi setiap pengguna.
\end{abstract}

\section{Kata Kunci: Pembayaran, Aplikasi, Identifikasi Wajah}

\begin{abstract}
This research aims to determine the level of accuracy of facial expression recognition systems if used as a payment system for a company sale and purchase transaction. The method of this research was descriptive, qualitative, and supported by literature studies. The results show that facial expression recognition systems are effective when applied to the payment system. It presents from the level of recognition accuracy and effectiveness in facial expression recognition which is higher than the failure rate, and the ability to detect faces is fast. Next, incorporating liveness detection technology into facial expression recognition will prevent spoof attacks made by non-real pictures such as portrait photos. Therefore, it can be concluded that the facial expression recognition system may become one of the most widely implemented systems in the future. It is due to the ease of transactions which will provide convenience for each user.
\end{abstract}




\section{Keywords: Payment, Application, Facial Recognition}

\section{PENDAHULUAN}

Seiring dengan terus berkembangnya ilmu pengetahuan dan teknologi yang membawa kebaruan dan kenyamanan bagi manusia dalam berbagai aspek kehidupan, teknologi baru telah muncul, membuat aktivitas manusia lebih mudah, termasuk pembayaran. Salah satu teknologi baru adalah Pengenalan Ekspresi Wajah yang diterapkan pada mesin Point of Sale di restoran dan kafe sehingga pembayaran hanya dapat dilakukan dengan mengenali ekspresi pelanggan. Facial Expression Recognition (FER) adalah sistem untuk mengenali ekspresi dari wajah seseorang[1]. Dalam contoh pertama, teknologi FER banyak digunakan di sektor keamanan. Akhirakhir ini, Pengenalan Ekspresi Wajah mulai digunakan atau diterapkan di berbagai sektor. Baru-baru ini, FER telah diterapkan pada sistem aplikasi Point of Sale di restoran. Point of Sale adalah sistem yang menangani transaksi bisnis. Umumnya, sistem ini terdiri dari aplikasi pelayan sebagai pesanan makanan atau minuman, aplikasi kasir sebagai aplikasi pencatatan pembayaran atau kasir, dan aplikasi laporan sebagai monitor kinerja. [2].

Ekspresi wajah adalah salah satu karakteristik perilaku. Berbagai algoritma dikembangkan untuk pengenalan ekspresi wajah. Efisiensi pengenalan tergantung pada metode ekstraksi fitur yang diadopsi.
Algoritma evolusioner seperti jaringan saraf, logika fuzzy. Juga termasuk dalam algoritma pengenalan wajah untuk meningkatkan tingkat pengenalan [3]. Berdasarkan penelitian sebelumnya yang dilakukan oleh Phankokkruad dan Jaturawat pada tahun 2017, pengenalan ekspresi wajah menggunakan metode LBPH (Local Binary Pattern Histogram)

menghasilkan tingkat akurasi $81,67 \%$ pada menghasilkan tingkat akurasi $81,67 \%$ pada still imagebased testing [4]. Selain menggunakan metode LBPH, ada juga metode fisher face. Hegde dan rekannya menerapkan metode Fisherface dalam penelitian mereka pada tahun 2018. Metode Fisherface memverifikasi ekspresi wajah manusia dengan membandingkan hasil pengenalan wajah dengan database yang dimiliki sebelumnya [5]. Metode lain yang sering digunakan untuk mengukur akurasi dalam teknologi pengenalan ekspresi wajah lainnya adalah Principal Component Analysis (PCA). Metode ini digunakan oleh Ramadhani dkk pada tahun 2017 dengan menerapkan pendekatan Algoritma Eigenfaces. [6]. Berbeda dengan penelitian sebelumnya, Mayya dkk. menggunakan metode Deep Convolutional Neural Network (DCNN) untuk penelitian mereka pada tahun 2016. [7]. 
Mahmood et al. pada tahun 2018 mencoba meningkatkan akurasi pengakuan dengan menggunakan metode transformasi Radon dan gelombang Gabor berubah bersama dengan pengklasifikasi yang kuat. [8]. Tingkat akurasi pengenalan ekspresi wajah juga dapat diukur dengan menggunakan metode Multi Class Fisher Discriminant Analysis (MCFDA). Metode ini digunakan oleh Pane dkk. pada tahun 2018. [9]. Selain itu, untuk mengukur akurasi pengenalan ekspresi wajah, deteksi keaktifan wajah juga harus dilakukan untuk mencegah penipuan atau spoofing. Deteksi aktivitas wajah dapat dilakukan dengan mengekstraksi area mata. Titik fitur yang diekstraksi akan ditelusuri untuk meminimalkan gerakan kepala seseorang dan mendapatkan area mata yang stabil menggunakan algoritma Kanade-Lucas-Tomasi (TLC). Area mata dipotong dari bingkai kamera real-time dan diputar untuk mendapatkan area mata yang stabil. Hal ini dapat mendeteksi wajah orang yang aktif agar tidak terjadi spoofing.

Berbeda dengan penelitian sebelumnya yang hanya berfokus pada pengukuran akurasi pengenalan ekspresi wajah. Penelitian ini dilakukan untuk mengukur akurasi dan pendeteksian keaktifan wajah pada sistem pengenalan ekspresi wajah dan mengetahui tingkat keefektifan sistem tersebut ketika diterapkan pada sistem aplikasi point of sale. Metode yang digunakan dalam penelitian ini adalah deskriptif kualitatif dengan menggunakan metode eksplorasi atau pengumpulan data berdasarkan fokus penelitian dan orientasi bacaan (studi kepustakaan).

\section{LANDASAN TEORI}

Referensi (Havaldar, 2000) menjelaskan

bahwa pengeditan manual pada karakter animasi diperlukan jika: 1) gerakan yang diharapkan dari model 3D belum sama/ mirip dengan pergerakan manusia,

2) wajah model $3 \mathrm{D}$ memiliki proporsi/ morfologi yang berbeda dari

wajah manusia, 3) penempatan marker pada motion capture tidak selalu tetap dan tepat dari hari ke hari. Pengenalan pola merupakan suatu ilmu yang digunakan untuk mengklasifikasikan sesuatu berdasarkan pengukuran ciri [14]. Wajah manusia mempunyai peran sentral dalam interaksi social, sehingga pemrosesan wajah merupakan sub penting dalam pengenalan pola [15].

\section{METODE PENELITIAN}

Penelitian ini tidak focus pada pengukuran dan perhitungan secara langsung. Melainkan, menggunakan metode deskriptif kualitatif dan studi literature untuk menentukn efektifitas pengenalan ekspresi 
wajah. Studi deskriptif kualitatif dilakukan dengan membaca dan mempelajari penelitian yang telah dilakukan. Berdasarkan jurnal ini, perbandingan dibuat mengenai hasil penelitian sebelumnya dan menilai tingkat akurasi dan efektifitas pengenalan ekspresi wajah.

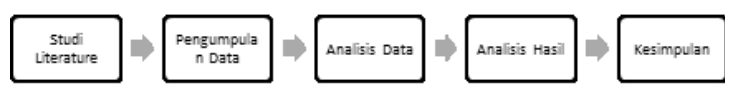

Gambar 1. Alur Penelitian

Pada tahaan alur penelitian meliputi pada lima tahapan yaitu Studi literature, pengumpulan data, analisis data, analisis hasil dan kesimpulan.

\section{Perencanaan Sistem}

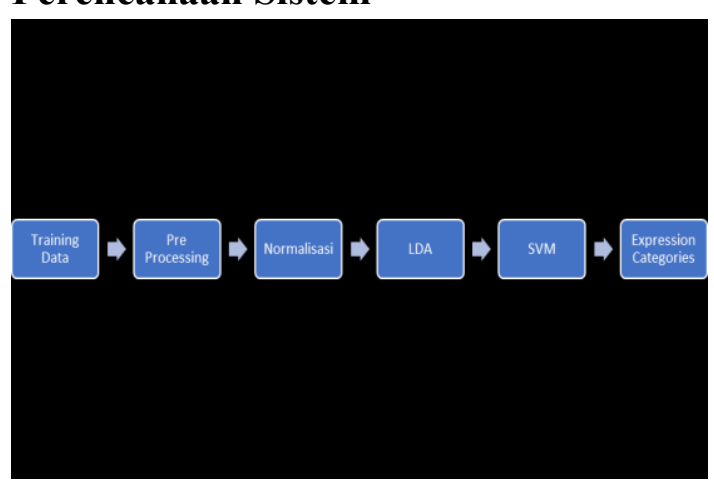

Gambar 2. Tahapan Cek Ekspresi

\section{HASIL}

Penelitian ini mengumpulkan data yang berfokus pada pengukuran akurasi dan kecepatan deteksi dalam sistem

pengenalan wajah dan

pengenalan ekspresi wajah dengan metode atau pendekatan yang berbeda berdasarkan beberapa sebelumnya. Tabel 1 menunjukkan pengenalan tingkat akurasi untuk ekspresi wajah dalam sistem pengenalan wajah dan pengenalan ekspresi wajah.

Tabel 1. Tabel Akurasi

\begin{tabular}{lc}
\hline \multicolumn{1}{c}{ Metode } & Akurasi \\
\hline Fisherface & $68,1 \%$ \\
LBPH & $81,67 \%$ \\
DCNN & $97,07 \%$ \\
Radon & \\
Transformation & $84,85 \%$ \\
dan GWT & \\
MC-FDA & $93,3 \%$ \\
\hline
\end{tabular}

Berdasarkan data akurasi yang tercantum dalam Tabel 1, tingkat akurasi pengenalan wajah dan sistem pengenalan ekspresi wajah dalam pengenalan wajah atau ekspresi wajah berjalan dengan baik. Hal ini karena tingkat kegagalan dalam proses pengakuan lebih rendah dari tingkat keberhasilan. Sistem pengenalan wajah dan pengenalan ekspresi wajah ini masih dapat dilatih untuk meningkatkan akurasi pengenalan wajah atau ekspresi wajah.

Penelitian ini dilakukan dengan menggunakan database yang ada untuk melatih dan menguji bahan untuk pengenalan wajah dan sistem pengenalan ekspresi wajah. Database adalah kumpulan gambar 
wajah dan ekspresi seseorang. Seperti pada metode Fisherface, pengenalan ekspresi wajah dilakukan dengan menggunakan sampel gambar yang dikumpulkan dari beberapa subjek. Studi ini melakukan uji coba pada 8 jenis ekspresi yang berbeda, termasuk kemarahan, kesedihan, kebahagiaan, jijik, kejutan, kebingungan, ketakutan, dan netralitas. Metode ini dapat bekerja secara efektif dengan gambar sampel tanpa batas dengan tingkat akurasi $68,1 \%$ dan menunjukkan hasil yang baik.

$\begin{array}{ccr}\text { Dalam } & \text { metode } & \text { Deep } \\ \text { Convolutional } & \text { Neural } & \text { Network }\end{array}$
(DCNN), mekanisme pengujian akurasi ekspresi wajah dilakukan dengan mengubah dan mengekstraksi gambar untuk mendapatkan hasil deteksi wajah menggunakan dua database utama, yaitu $\mathrm{CK}+$ dan JAFFE. Dalam database CK +, 188 subjek melakukan verifikasi ekspresi wajah yang terdiri dari berbagai emosi, seperti kemarahan, penghinaan, jijik, ketakutan, kebahagiaan, kesedihan, dan ketakutan. Hasil tes dalam database $\mathrm{CK}+$, ekspresi wajah yang dapat diverifikasi secara akurat adalah 314 dari 327 ekspresi yang direkam. Sedangkan pada database kedua, yaitu JAFFE, penelitian dilakukan pada 10 mata pelajaran dengan 6 ekspresi berbeda yang terdiri dari 213 ekspresi wajah. Untuk database JAFFE, ekspresi wajah yang dapat diverifikasi secara akurat adalah 209 gambar dari 213 ekspresi wajah $[11,12]$.
Kemudian, dalam metode Radon Transformation dan GWT (Gabor Wavelet Transformation), penelitian dilakukan dengan menggunakan urutan gambar yang dibagi menjadi tiga fase. Tahap pertama adalah proses deteksi wajah, yaitu menentukan parameter oval untuk pembatasan sudut wajah dan keselarasan wajah. Tahap kedua adalah proses representasi fitur dan fase ekstraksi. Kemudian fase terakhir adalah fase klasifikasi pengenalan dan penilaian ekspresi wajah. Penelitian ini melakukan eksperimen pada dua set data patokan publik seperti CohnKanade dan dataset AT \&T. Ini terdiri dari 486 urutan data ekspresi wajah untuk Cohn-Kanade dan 400 dataset AT \&T. Para peneliti menggabungkan transformasi radon dan filter Gabor untuk mengekstrak fitur wajah dan memperoleh hasil yang menjanjikan di kedua kumpulan data. Hasil yang diperoleh dari percobaan yang dilakukan menunjukkan bahwa tingkat akurasi rata-rata adalah $86 \%$ untuk data Cohn-Kanade dan 83,7\% untuk data AT \&T.

Metode berikutnya adalah metode Multiclass Discriminant Analysis (MC-FDA) dan Principal Component Analysis (PCA). Pengenalan emosional dilakukan dengan menggunakan dua klasifikasi, yaitu, LDA dan SVM, untuk menilai tiga kelas emosional 
yang berbeda: positif, negatif, dan netral. Tes MC-FDA diterapkan pada dataset SEED publik, dan percobaan ini dilakukan pada 15 subjek yang merekam data. Proses pengujian ini terdiri dari 3 skenario: menguji setiap individu, menguji setiap sesi, dan menguji semua data. Dalam skenario pertama, dengan menggunakan klasifikasi LDA dan SVM dengan MCFDA, hasil akurasi data yang diukur memperoleh tingkat akurasi 27,3 poin dan 19,3 poin. Sedangkan untuk metode PCA, hasil klasifikasi yang diperoleh adalah 10,8 poin dan 2,08 poin. Untuk skenario kedua, MC-PDA juga lebih unggul dalam uji coba ini dibandingkan dengan metode PCA. Dalam skenario terakhir, hasil metode MC-FDA dengan klasifikasi LDA memperoleh tingkat akurasi 93,3\% dan 3,5 poin, sedangkan metode PCA dengan klasifikasi SVM memperoleh tingkat akurasi $78,4 \%$ dan 12,8 poin. Hasil uji coba yang telah dilakukan menunjukkan bahwa metode MC-FDA lebih unggul dalam penelitian ini.

Secara sederhana, proses kerja sistem pengenalan ekspresi wajah dengan objek yang berasal dari database dalam pengenalan ekspresi ditunjukkan pada Gambar 1.

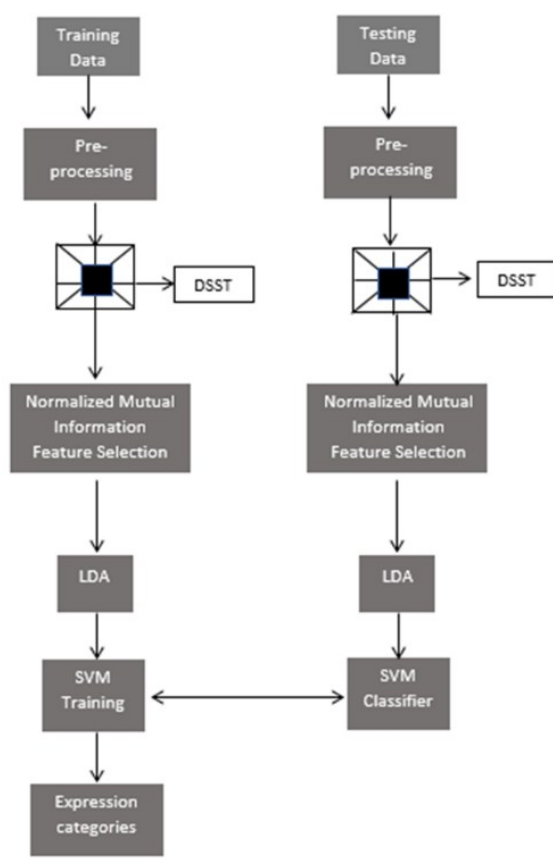

Gambar 3. Flowchart Sistem

Tidak seperti penelitian lain, penelitian yang dilakukan oleh Phankokkruad dan Jaturawat pada tahun 2017, dengan metode LBPH, melakukan tes dengan mengambil gambar diam dengan berbagai ekspresi wajah yang diperoleh dari beberapa individu yang merupakan subjek penelitian yang mengukur tingkat akurasi dalam sistem pengenalan ekspresi wajah. Dua faktor harus dipertimbangkan selama proses pemotretan: perspektif refleksi wajah dan cahaya untuk mendapatkan kualitas gambar yang baik untuk proses penelitian. Setelah melakukan penelitian, tingkat akurasi yang diperoleh adalah $81,67 \%$. Ini berarti bahwa metode ini dapat secara stabil dan 
akurat memverifikasi database gambar. Selain mempertimbangkan keakuratan sistem pengenalan, sistem pengenalan wajah dan pengenalan ekspresi wajah ini harus mempertimbangkan kecepatan dan kemampuan untuk mendeteksi objek, seperti wajah atau ekspresi wajah. Kecepatan deteksi ekspresi wajah dalam sistem pengenalan ekspresi wajah ini sebelumnya diukur oleh Ramadhani dkk pada tahun 2017. Penelitian ini menggunakan metode PCA dengan pendekatan eigenface. Hasil penelitian menunjukkan bahwa sistem pengenalan ekspresi wajah sangat cepat dalam mendeteksi objek, yang hanya membutuhkan waktu kurang dari 1 detik untuk mengidentifikasi wajah.

Akurasi dan kecepatan mendeteksi sistem bukan satu-satunya hal penting yang harus dipertimbangkan untuk menentukan efektivitas penerapan sistem pengenalan ekspresi wajah dalam sistem point of sale. Dalam hal ini, keamanan menjadi sangat penting jika sistem pengenalan ekspresi wajah diterapkan pada sistem point of sale karena kedua sistem tersebut digunakan sebagai metode atau alat untuk masalah pembayaran. Oleh karena itu, deteksi aktif wajah juga harus diterapkan untuk mencegah penipuan. Untuk mendeteksi aktivitas wajah, sistem dapat menggunakan metode Liveness dengan Haar-Cascade Classifier untuk mengekstrak area mata dan algoritma Kanade-LucasTomasi (TLC) untuk memverifikasi area mata. Metode ini digunakan oleh Killioğlu et al. pada tahun 2017. Metode ini berhasil mendeteksi objek (active face/nonphotos) dengan tingkat keberhasilan $89,7 \%$. Akurasi dan kecepatan mendeteksi sistem bukan satusatunya hal penting yang harus dipertimbangkan untuk menentukan efektivitas penerapan sistem pengenalan ekspresi wajah dalam sistem Point Of Sale.

Dalam hal ini, keamanan menjadi sangat penting jika sistem pengenalan ekspresi wajah karena kedua sistem tersebut digunakan sebagai metode atau alat untuk masalah pembayaran. Oleh karena itu, deteksi aktif wajah harus dilaksanakan untuk mencegah penipuan. Untuk mendeteksi aktivitas wajah, sistem dapat menggunakan metode Liveness dengan Haar-Cascade Classifier untuk mengekstrak area mata dan algoritma Kanade-Lucas-Tomasi (TLC) untuk memverifikasi area mata. Killioğlu menerapkan metode ini pada tahun 2017. Metode ini berhasil mendeteksi objek (active face/non-photos) dengan tingkat keberhasilan $89,7 \%$.

Dari hasil di atas, penerapan sistem pengenalan ekspresi wajah ini berjalan dengan baik dan aman bila dikombinasikan dengan beberapa metode sistem. Misalnya, 
untuk tingkat akurasi pengenalan, sistem pengenalan ekspresi wajah menerapkan metode Deep Convolutional Neural Network (DCNN) karena memiliki tingkat akurasi yang lebih tinggi dibandingkan dengan metode lain. Sistem pengenalan ekspresi wajah juga harus menerapkan metode PCA dengan pendekatan eigenface. Metode ini menciptakan waktu deteksi yang sangat cepat selama proses pengenalan objek. Karena menjaga alasan sistem keamanan, sistem dapat menerapkan deteksi keaktifan wajah (keaktifan), menggunakan Haar-Cascade Classifier untuk mengekstrak area mata dan algoritma Kanade-Lucas-Tomasi (TLC) untuk memverifikasi area mata. Kombinasi ini membuat sistem bekerja lebih baik.

Berikut ini menggambarkan cara menggunakan dan bekerja dengan mesin point of sale yang menerapkan sistem pengenalan ekspresi wajah ketika ada aktivitas pesanan dan pemrosesan pembayaran dalam sistem. Mulai dari proses pemesanan, seperti yang ditunjukkan pada Gambar 4.
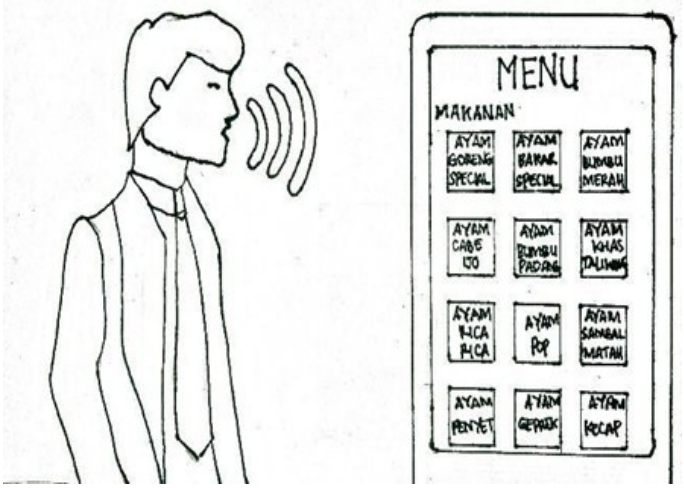

Gambar 4. Konsumen memesan makanan melalui POS

Gambar 4 menunjukkan aktivitas pemesanan yang dilakukan pada mesin Point of Sale yang menerapkan sistem pengenalan perintah suara untuk membuat pesanan dengan perintah suara. Setelah proses pemilihan pesanan selesai, pesan pemberitahuan akan muncul di sistem, menurut Gambar 5.

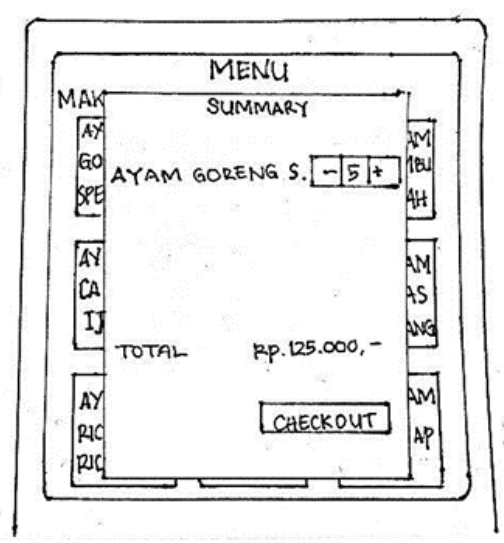

Gambar 5. Notifikasi Order

Pemberitahuan pada sistem pada Gambar 5 bertujuan untuk memberi tahu pelanggan tentang pesanan yang ditempatkan dan total 
yang harus dibayar untuk pesanan yang ditempatkan. Jika pelanggan yakin dan ingin membayar, pelanggan dapat mengatakan "Checkout." Pilihan platform pembayaran digital kemudian akan muncul yang dapat digunakan untuk pembayaran, seperti yang ditunjukkan pada Gambar 6.

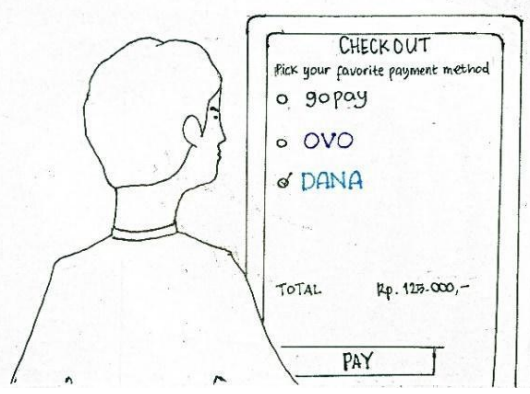

Gambar 6. Konsumen mengarahkan wajah ke POS untuk menyelesaikan transaksi

Penggunaan platform pembayaran digital di titik sistem penjualan ditunjukkan pada Gambar 6 bertujuan untuk pengurangan tanpa kontak dan tanpa uang tunai. Ini akan membuat pembayaran lebih mudah menggunakan penerapan sistem pengenalan ekspresi wajah. Setelah memilih platform pembayaran digital, pelanggan harus mengatakan "bayar" dan membuka aplikasi platform pembayaran digital untuk mengkonfirmasi aktivitas transaksi. Setelah itu, pelanggan menghadapi mesin point of sale, dan proses pengenalan ekspresi wajah terjadi di wajah pelanggan, seperti yang ditunjukkan pada Gambar 7.

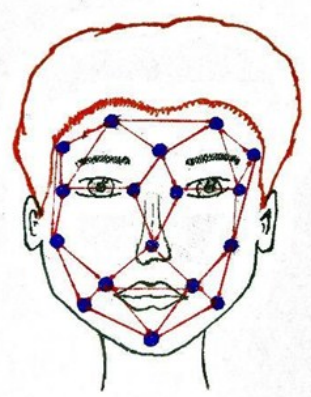

Gambar 7. Proses Rekognisi Ekspresi Wajah

Proses Pengenalan Ekspresi Wajah ini bekerja sesuai dengan sistem yang telah diprogram sebelumnya. Misalnya, untuk melakukan transaksi pembayaran, pelanggan diminta untuk tersenyum. Kemudian sistem akan secara otomatis melakukan pengenalan wajah pelanggan sesuai dengan pesanan yang telah diprogram, dan jika ekspresi pelanggan telah berhasil dikenali, sistem akan secara otomatis membayarnya dengan sukses. Berikut ini adalah contoh pemberitahuan pembayaran yang dapat kita lihat di Gambar 8 .

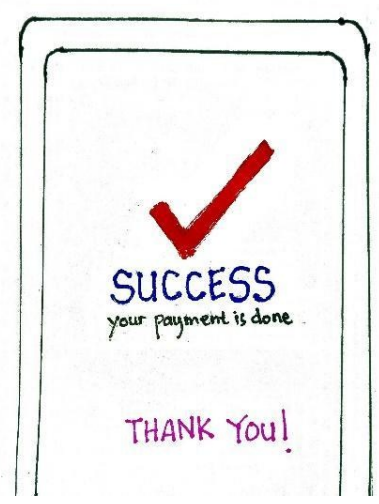

Gambar 8. Notifikasi berhasil transaksi 
Jika pemberitahuan muncul, itu berarti bahwa proses pembayaran telah berhasil dilakukan. Pelanggan tidak perlu khawatir tentang kesalahan dalam sistem karena sistem pembayaran pada mesin Point of Sale terintegrasi dengan platform pembayaran digital. Pelanggan dapat membatalkan aktivitas pembayaran jika aktivitas tidak sesuai, dan proses pembayaran memerlukan konfirmasi sebelum proses pengenalan ekspresi wajah dilakukan. Sistem kerja mesin point of sale telah terintegrasi dengan platform pembayaran digital sehingga tingkat keamanan lebih tinggi, sehingga pembeli tidak perlu khawatir tentang kesalahan dan telah diminimalkan bahkan mendekati akurasi.

\section{KESIMPULAN}

Facial Expression Recognition System sangat efektif jika diterapkan pada Point of Sale (POS) untuk digunakan sebagai sistem pembayaran di masa depan. Sistem ini dapat mendeteksi dan mengidentifikasi objek (wajah) dalam waktu singkat, dan keakuratan pengenalan ekspresi wajah dapat diidentifikasi dengan baik. Selain itu, keamanan pada sistem dapat diandalkan oleh penggunanya. Penerapan pengenalan wajah di Point of Sale ini akan menjadi solusi yang tepat selama pandemi akibat penurunan kontak langsung dalam sistem pembayaran (contactless), yang akan memberikan kemudahan dan kenyamanan kepada pengguna dalam transaksi jual beli.

\section{DAFTAR PUSTAKA}

[1]Hammed, S. S., Sabanayagam, A., \& Ramakalaivani, E. 2020. A Review On Facial Expression Recognition Systems. Journal of Critical Reviews, 7(4), pp. 903-905..

[2]Dharmaadi, I. P. A., \& Sasmitha, G. M. A. 2018. Perancangan Sistem Informasi Restoran Terintegrasi Berbasis Java Web Socket Online. Jurnal Penelitian Pos dan Informatika, 8(1), pp. 51-62. [3]Anil, J., \& Suresh, L. P. 2016. Literature survey on face and face expression recognition. In 2016 International Conference on Circuit, Power and Computing Technologies (ICCPCT) (pp. 1-6). IEEE.

[4]Phankokkruad, M., \& Jaturawat, P. 2017. Influence of facial expression and viewpoint variations on face recognition accuracy by different face recognition algorithms. In 2017 18th IEEE/ACIS International Conference on Software Engineering, Artificial Intelligence, Networking and Parallel/Distributed Computing (SNPD) (pp. 231237). IEEE. 
[5]Hegde, N., Preetha, S., \& Bhagwat, S. 2018. Facial Expression Classifier Using Better Technique: FisherFace Algorithm. In 2018 International Conference on Advances in Computing, Communications and Informatics (ICACCI) (pp. 604-610). IEEE

[6]Ramadhani, A. L., Musa, P., \& Wibowo, E. P. 2017. Human face recognition application using PCA and eigenface approach. In 2017 Second International Conference on Informatics and Computing (ICIC) (pp. 1-5). IEEE.

[7]Mayya, V., Pai, R. M., \& Pai, M. M. 2016. Automatic facial expression recognition using $D C N N$. Procedia Computer Science, 93, 453-461.

[8]Mahmood, M., Jalal, A., \& Evans, H. A. 2018. Facial expression recognition in image sequences using $1 D$ transform and Gabor wavelet transform. In 2018 International Conference on Applied and Engineering Mathematics (ICAEM) (pp. 1-6). IEEE.

[9]Pane, E. S., Wibawa, A. D., \& Purnomo, M. H. 2018. Peningkatan Akurasi Identifikasi Emosi pada Sinyal Electroencephalograpy

Menggunakan Multiclass Fisher Discriminant Analysis. Jurnal Nasional Teknik Elektro dan
Teknologi Informasi (JNTETI), 7(4), 437-443. [10]Killioğlu, M., Taşkiran, M., \& Kahraman, N. 2017. Antispoofing in face recognition with liveness detection using pupil tracking. In 2017 IEEE 15th International Symposium on Applied Machine Intelligence and Informatics (SAMI) (pp. 000087-000092). IEEE

[11]Mulyana, A., Rusmana, D., \& Rafdhi, A. A. 2021. Application platform for $e$ reservation system in traditional show. In Journal of Physics: Conference Series, 1764(1), p. 012197.

[12]Soegoto, E. S., Arifin, F. H., \& Oktafiani, D. 2021. Information system for waste bank savings. In Journal of Physics: Conference Series, 1764(1), p. 012192.

[13]Gaol, T. V. L., \& Gustira, M. R. 2020. Utilization of Information and Communication Technology in Agriculture. In IOP Conference Series: Materials Science and Engineering, 879(1), p. 012143

[14]Muhathir, M. (2018). Klasifikasi Ekspresi Wajah Menggunakan Bag Of Visual Words. Journal Of Informatics And Telecommunication Engineering, 1(2), 73-81. 
[15]Rere, L. R. (2019). Studi

Pengenalan Ekspresi Wajah Berbasis Convolutional Neural Network. Prosiding

SeNTIK, 3(1), 71-78. 